Journal of Research in Nursing

Vol. 1, No. 1, 2015

Print ISSN 2244-2723

University of Cebu

Cebu City, Cebu, Philippines

\title{
Community Health Needs of Barangay Hipodromo, Cebu City, Cebu, Philippines
}

\author{
Claude Patrick V. Montecillo \\ Mauro Allan P. Amparado
}

\section{Abstract}

This study assessed the community health needs of Barangay Hipodromo, Cebu City, Cebu, Philippines. It further described the profile of the community in terms of: family structure and its characteristics; socio-economic status; home and environment status; health practices; and identified community health concerns of the respondents. The key findings were the bases of the proposed action plan.

A descriptive research design was utilized with a researchermodified questionnaire and follow-up interviews of 308 respondents. Treatment of data included frequency, simple percentage, sum of ranks, and common themes.

The findings showed that a majority of the respondents belong to the age bracket of 40-49 years old, married, has a nuclear type of family consisting of 3-4 children, unemployed with a monthly income of less than 5,000 Philippine pesos, had high school education, and Roman Catholics. Homes are owned, made up of mixed materials; uses electricity; has a private source of drinking water; uses charcoal and firewood for cooking; has open drainage system; disposes garbage with open containers as method of 
waste segregation; has water-sealed latrines; backyard garden has ornamental plants and raises chickens; seeks professional help from the barangay health station; colds, cough and influenza were the common illnesses in the past six months; they self-medicate as initial treatment; claims that hypertension is their heredo-familial disease; breastfeeds their infants; completed immunization status of the first child; utilizes the barangay health station for medical and dental check-up; does not practice family planning methods.

Based on the findings of the study, the community health needs were identified with pressing concerns on drugs, alcoholism, poor ventilation, noise pollution, and availability of medicines and supplies in the barangay health station. As a result, the researchers recommended the immediate implementation of the proposed action plan.

Recommended citation: Montecillo, C. P. V. \& Amparado, M. A. P. (2015). Community Health Needs of Barangay Hipodromo, Cebu City, Cebu, Philippines. Journal of Research in Nursing, 1(1), 2029. 